\title{
PENGARUH CORPORATE SOCIAL RESPONSIBILITY, KEPUTUSAN INVESTASI, DAN STRUKTUR MODAL TERHADAP NILAI PERUSAHAAN
}

\author{
Ardianti Fajriana \\ Prodi Akuntansi Universitas Negeri Yogyakarta \\ ardiantifajriana@gmail.com
}

Denies Priantinah

Staf Pengajar Jurusan Pendidikan Akuntansi Universitas Negeri Yogyakarta

\begin{abstract}
Abstrak: Pengaruh Corporate Social Responsibility, Keputusan Investasi, Dan Struktur Modal Terhadap Nilai Perusahaan. Penelitian ini bertujuan mengetahui pengaruh CSR, Keputusan Investasi, Dan Struktur Modal Terhadap Nilai Perusahaan dimoderasi Kepemilikan Manajerial pada perusahaan pertambangan yang terdaftar di BEI periode 2008-2014. Desain penelitian adalah asosiatif kausal. Populasi penelitian adalah perusahaan pertambangan dengan pemilihan sampel melalui metode purposive sampling. Terdapat 11 perusahaan yang memenuhi kriteria sebagai sampel penelitian. Teknik analisis data menggunakan analisis regresi sederhana, analisis regresi nilai selisih mutlak, dan analisis regresi berganda. Hasil penelitian menunjukkan bahwa (1) CSR berpengaruh positif tidak signifikan terhadap Nilai Perusahaan, (2) Keputusan Investasi berpengaruh positif signifikan terhadap Nilai Perusahaan, (3) Struktur Modal berpengaruh negatif signifikan terhadap Nilai Perusahaan, (4) Kepemilikan Manajerial memoderasi CSR terhadap Nilai Perusahaan, (5) Kepemilikan Manajerial memoderasi Keputusan Investasi terhadap Nilai Perusahaan, (6) Kepemilikan Manajerial tidak memoderasi Struktur Modal terhadap Nilai Perusahaan, (7) CSR, Keputusan Investasi, dan Struktur Modal bersama-sama memengaruhi Nilai Perusahaan.
\end{abstract}

Kata kunci: Nilai Perusahaan, CSR, Keputusan Investasi, Struktur Modal, Kepemilikan Manajerial.

Abstract: Effect Corporate Social Responsiblity, Investment Decisions, Capital Structure To Firm Value. This research aimed to determine effect CSR, Investment Decisions, Capital Structure to Firm Value with Managerial Ownership as Moderating Variable in Minning Company in BEI on 20082014. Research type was causal assosiative. Population was minning company and sampling methode used purposive sampling. There were 11 company fulfilled criterion as sampling. Analysis technique used was simple regression analysis, regression analysis test of the absolut value of the difference, and multiple regression analysis. The results were : (1) CSR influence positive insignificant to Firm Value, (2) Investment Decisions influence positive significant to Firm Value, (3)Capital Structure influence negative significant to Firm Value, (4) Managerial Ownership moderate the influence of CSR to Firm Value, (5) Managerial Ownership moderate the influence of Investment Decisions to Firm Value, 6) Managerial Ownership can not moderate the influence of Capital Structure to Firm Value, (7) Simultaneously CSR, Investment Decisions, Capital Structure influence to Firm Value.

Keywords: Firm Value, CSR, Investment Decisions, Capital Structure, Managerial Ownership.

\section{PENDAHULUAN}

Perusahaan didefinisikan sebagai suatu organisasi yang didirikan perorangan, sekelompok orang atau badan lain. Perusahaan melakukan kegiatan berupa produksi dan distribusi dengan tujuan untuk memenuhi kebutuhan ekonomis manusia (Soemarso, S.R., 2004: 22). Setiap perusahaan memiliki tujuan yang ditetapkan, baik tujuan jangka pendek 


\section{JURNAL NOMINAL / VOLUME V NOMOR 2 / TAHUN 2016}

maupun jangka panjang. Berkaitan dengan tujuan jangka panjang, perusahaan yang telah go public akan selalu berusaha untuk memaksimalkan nilai perusahaan. Nilai perusahaan berhubungan dengan harga saham sehingga dapat dikatakan bahwa dengan meningkatnya nilai perusahaan akan berdampak juga pada peningkatan kemakmuran pemegang saham (Rika Nurlela dan Islahudin, 2008: 7).

Pencapaian tujuan jangka panjang perusahaan sejalan dengan pelaksanaan CSR. CSR dijadikan sebagai bentuk pertanggungjawaban perusahaan terhadap lingkungan dan masyakarat. Penerapan CSR tidak lagi dianggap sebagai cost, tetapi investasi perusahaan seiring semakin pentingnya CSR bagi perusahaan (Sutopoyudo, 2009). Pelaksanaan CSR telah diatur dalam Undang-Undang No. 25 Tahun 2007 tentang Penanaman Modal dan UU Nomor 40 Tahun 2007 Tentang Perseroan Terbatas (UU PT). Namun, peraturan tersebut belum mampu meningkatkan jumlah perusahaan yang menerapkan CSR.

Rendahnya tingkat pelaksanaan dan pengungkapan CSR ini akan menghambat perusahaan dalam hal memperoleh kepercayaan dari investor karena CSR menjadi salah satu hal yang diperhatikan investor ketika akan berinvestasi di sebuah perusahaan.

Keputusan investasi menjadi aspek yang menentukan apakah pemegang saham bersedia untuk berinvestasi dalam perusahaan tersebut atau tidak. Menurut Riskin Hidayat (2010: 458), keputusan investasi menjadi faktor penting dalam fungsi keuangan perusahaan dan faktor penentu nilai perusahaan.

Myers (1970) dalam Lihan Rini Puspo Wijaya dan Bandi Anas Wibawa (2010: 6) memperkenalkan Investment Opportunity Set (IOS) dalam studi yang berkaitan dengan keputusan investasi. IOS diartikan sebagai kombinasi antara aktiva yang dimiliki (assets in place) dan pilihan investasi di masa yang akan datang dengan net present value positif.

Struktur modal berkaitan dengan proporsi pendanaan yang akan digunakan oleh perusahaan. Struktur modal yang optimal diperlukan untuk memaksimalkan nilai perusahaan. Struktur modal optimal adalah struktur yang akan memaksimalkan harga saham perusahaan. Struktur ini pada umumnya menginginkan rasio utang yang lebih rendah dibandingkan rasio untuk memaksimalkan Earning Per Share (EPS) yang diharapkan (Brigham dan Houston, 2011: 171).

Permasalahan lain yang turut memengaruhi nilai perusahaan, yaitu kepemilikan manajerial. Pihak manajemen sebagai pengelola perusahaan akan selalu berusaha untuk memaksimalkan nilai perusahaan sebagai bentuk tujuan jangka panjang perusahaan. Brigham dan Houston 


\section{JURNAL NOMINAL / VOLUME V NOMOR 2 / TAHUN 2016}

(2010: 8) menyebutkan bahwa tujuan dari manajemen adalah mengambil sekumpulan keputusan yang dapat menghasilkan harga saham maksimal karena hal ini akan memaksimalkan kekayaan pemegang saham.

Pihak manajemen diharapkan bertindak dan mengambil keputusan untuk kepentingan pemegang saham. Namun, dalam praktiknya sering terjadi konflik antara pihak manajemen dengan pemegang saham yang disebut dengan konflik keagenan (agency conflict). Konflik keagenan muncul ketika proporsi kepemilikan manajer atas saham perusahaan kurang dari $100 \%$. Hal ini menimbulkan kecenderungan akan adanya prioritas terhadap kepentingan pribadi sehingga pihak manajemen tidak lagi berorientasi terhadap tujuan perusahaan, yaitu memaksimalkan nilai perusahaan dalam pengambilan keputusan keuangan, khususnya keputusan pendanaan (Suad Husnan, 2008).

\section{METODE PENELITIAN}

\section{Jenis Penelitian}

Berdasarkan jenis data dan analisis yang digunakan, penelitian ini termasuk dalam penelitian kuantitatif karena mengacu pada perhitungan data berupa angka.

\section{Waktu dan Tempat Penelitian}

Penelitian ini dilakukan dengan pengambilan data di Bursa Efek Indonesia (BEI) melalui situs web www.idx.co.id dan
Indonesian Capital Market Library (ICAMEL) melalui situs www.icamel.id. Waktu pelaksanaan penelitian ini adalah dari bulan Desember 2015-Februari 2016.

\section{Target/Subjek Penelitian}

Populasi dalam penelitian ini adalah 40 perusahaan pertambangan yang terdaftar di Bursa Efek Indonesia periode 2008-2014. Metode pengambilan sampel adalah menggunakan purposive sampling. Berdasarkan kriteria yang telah ditentukan menggunakan metode purposive sampling, terdapat 11 perusahaan pertambangan yang terdaftar di Bursa Efek Indonesia selama tahun 2008 sampai dengan 2014 yang dijadikan sampel.

Data, Instrumen, dan Teknik Pengumpulan

Metode pengumpulan data yang digunakan dalam penelitian ini adalah dokumentasi, yaitu mengumpulkan dokumen yang dibutuhan secara online dengan mengambil data melalui website resmi Bursa Efek Indonesia. Metode pengumpulan data dokumentasi digunakan dalam rangka memenuhi data atau informasi yang diperlukan untuk kepentingan variabel penelitian yang telah didesain sebelumnya (Puguh Suharso, 2009: 104).

Penelitian ini juga menggunakan teknik content analysis, yaitu cara pemberian skor pada pengungkapan sosial laporan tahunan atau laporan keberlanjutan dengan mengamati tiap item yang 


\section{JURNAL NOMINAL / VOLUME V NOMOR 2 / TAHUN 2016}

diungkapkan diberi nilai 1 dan 0 untuk item yang tidak diungkapkan dalam laporan tahunan atau laporan keberlanjutan.

\section{Teknik Analisis Data}

\section{Uji Hipotesis}

Penelitian ini dalam melakukan pengujian terhadap hipotesis adalah menggunakan analisis regresi linear sederhana, analisis regresi nilai selisih mutlak, dan analisis regresi linear berganda.

\section{HASIL}

\section{PENELITIAN}

DAN

\section{PEMBAHASAN}

Variabel yang diukur dalam penelitian ini diproksikan dengan Nilai Perusahaan (Tobin's Q), Corporate Social Responsibility (CSR), Keputusan Investasi (Market to Book Value of Equity Ratio/MBVE), Struktur Modal (DER), dan Kepemilikan Manajerial (K. MANJ).

\section{Uji Hipotesis}

Berikut adalah persamaan regresi dalam penelitian ini :

1: $\mathrm{Y}=\alpha+\beta_{1} \mathrm{CSR}+\varepsilon$

2: $\mathrm{Y}=\alpha+\beta_{2} \mathrm{MBVE}+\varepsilon$

3: $\mathrm{Y}=\alpha+\beta_{3} \mathrm{DER}+\varepsilon$

4: Y $=\alpha+\beta_{1}$ ZCSR $+\beta_{4}$ ZK.MANJ $+\beta_{5}$

$$
\text { AbsCSR - K.MANJ }+\varepsilon
$$

5: Y $=\alpha+\beta_{2}$ ZMBVE $+\beta_{4}$ ZK.MANJ $+\beta_{6}$ AbsMBVE - K.MANJ $+\varepsilon$

6: $\mathrm{Y}=\alpha+\beta_{3}$ ZDER $+\beta_{4}$ ZK.MANJ $+\beta_{7}$ AbsDER - K.MANJ + $\varepsilon$

7: $\mathrm{Y}=\alpha+\beta_{1} \mathrm{CSR}+\beta_{2} \mathrm{MBVE}+\beta_{3} \mathrm{DER}+$

\section{Hasil Uji Hipotesis 1}

Tabel 1. Ringkasan Hasil Uji Hipotesis 1

Variab B Beta $t_{\text {hitung }} t_{\text {tabel }}$ Sig.

el

\begin{tabular}{llllll}
\hline CSR & 0,23 & 0,22 & 1,19 & 1,66 & 0,23 \\
& 8 & 3 & 5 & 6 & 6
\end{tabular}

Berdasarkan tabel 1, persamaan regresi adalah :

Tobin's $\mathrm{Q}=0,238+0,223 \mathrm{CSR}$

Berdasarkan tabel 1, dapat dilihat bahwa nilai $t_{\text {hitung }}$ sebesar 1,195 sedangkan $\mathrm{t}_{\text {tabel }}$ pada tingkat signifikansi $5 \%$ sebesar 1,666. Hasil ini menunjukkan bahwa thitung lebih kecil dari $t_{\text {tabel }}(1,195<1,666)$. Nilai probabilitas signifikansi sebesar 0,236 menunjukkan nilai yang lebih besar dari nilai pada tingkat signifikansi yang telah ditentukan sebelumnya, yaitu 0,05 (0,236 > 0,05). Berdasarkan hasil uji hipotesis tersebut dapat disimpulkan bahwa variabel CSR memiliki pengaruh positif tetapi tidak signifikan terhadap Nilai Perusahaan (Tobin's Q).

Hasil penelitian ini sesuai dengan hasil penelitian Rika Nurlela dan Islahudin (2008) serta Laras Surya Ramadhani dan Basuki Hadiprajitno (2012). Hasil penelitian tersebut menyimpulkan bahwa CSR tidak berpengaruh terhadap Nilai Perusahaan. Hasil penelitian ini tidak memberikan dukungan empiris bahwa perusahaan yang telah melaksanakan CSR dan 


\section{JURNAL NOMINAL / VOLUME V NOMOR 2 / TAHUN 2016}

mengungkapkan informasi tanggung jawab sosialnya secara lebih luas akan memiliki nilai perusahaan yang tinggi. Rendahnya kualitas pengungkapan CSR dan belum mengikuti standar yang dikeluarkan oleh GRI menjadi faktor yang menyebabkan praktik CSR tidak berpengaruh terhadap nilai perusahaan.

\section{Hasil Uji Hipotesis 2}

Tabel 2. Ringkasan Hasil Uji Hipotesis 2

\begin{tabular}{llllll}
\hline Variabel & $\mathrm{B}$ & $\mathrm{Beta}$ & $\mathrm{t}_{\text {hitung }}$ & $\mathrm{t}_{\text {tabel }}$ & Sig. \\
\hline MBVE & 0,058 & 0,595 & 15,902 & 1,666 & 0,000
\end{tabular}

Berdasarkan tabel 2, persamaan regresi adalah :

Tobin's $\mathrm{Q}=0,058+0,595 \mathrm{MBVE}$

Berdasarkan tabel 2, dapat dilihat bahwa nilai thitung sebesar 15,902 sedangkan $\mathrm{t}_{\text {tabel }}$ pada tingkat signifikansi $5 \%$ sebesar 1,666. Hasil ini menunjukkan bahwa thitung lebih besar dari tabel $(15,902>1,666)$. Nilai probabilitas signifikansi sebesar 0,000 menunjukkan nilai yang lebih kecil dari nilai pada tingkat signifikansi yang telah ditentukan sebelumnya, yaitu 0,05 (0,000> 0,05). Berdasarkan hasil uji hipotesis tersebut dapat disimpulkan bahwa variabel Keputusan Investasi (MBVE) memiliki pengaruh positif dan signifikan terhadap Nilai Perusahaan (Tobin's Q).

Hasil penelitian ini sesuai dengan hasil penelitian Lihan Rini Puspo Wijaya dan Bandi Anas Wibawa (2010) serta Arie Afzal dan Abdul Rohman (2012). Hasil penelitian tersebut menyimpulkan bahwa keputusan investasi berpengaruh positif dan signifikan terhadap nilai perusahaan. Pengaruh langsung keputusan investasi terhadap nilai perusahaan merupakan hasil yang diperoleh dari kegiatan investasi itu sendiri melalui pemilihan proyek atau kebijakan lainnya, yaitu seperti menciptakan produk baru, penggantian mesin yang lebih efisien, pengembangan research dan development.

\section{Hasil Uji Hipotesis 3}

Tabel 3. Ringkasan Hasil Uji Hipotesis 3

\begin{tabular}{llllll}
\hline $\begin{array}{l}\text { Variab } \\
\text { el }\end{array}$ & B & Beta & $t_{\text {hitung }}$ & $t_{\text {tabel }}$ & Sig. \\
\hline DER & 0,16 & - & - & - & 0,02 \\
& 3 & 0,24 & 2,23 & 1,66 & 8 \\
& & 3 & 8 & 6 & \\
& & & & & \\
\end{tabular}

Berdasarkan tabel 3, persamaan regresi adalah :

Tobin's $\mathrm{Q}=0,163-0,243$ DER

Berdasarkan tabel 3, dapat dilihat bahwa nilai thitung sebesar -2,238 sedangkan $\mathrm{t}_{\text {tabel }}$ pada tingkat signifikansi $5 \%$ sebesar 1,666. Hasil ini menunjukkan bahwa thitung lebih besar dari $t_{\text {tabel }}(-2,238>-1,666)$. Nilai probabilitas signifikansi sebesar 0,028 menunjukkan nilai yang lebih kecil dari nilai pada tingkat signifikansi yang telah ditentukan sebelumnya, yaitu 0,05 (0,028 > 0,05). Berdasarkan hasil uji hipotesis tersebut dapat disimpulkan bahwa variabel Struktur Modal (DER) memiliki pengaruh negatif dan signifikan terhadap Nilai Perusahaan (Tobin's Q). 


\section{JURNAL NOMINAL / VOLUME V NOMOR 2 / TAHUN 2016}

Hasil penelitian ini sesuai dengan hasil penelitian Eli Safrida (2006). Hasil penelitian tersebut menyimpulkan bahwa struktur modal berpengaruh negatif dan signifikan terhadap nilai perusahaan. Penelitian tersebut menggunakan panduan titik optimum struktur modal berkisar di antara 0,3 sampai 0,4 . Hal ini memberikan implikasi bahwa kebijakan struktur modal perusahaan yang lebih banyak menggunakan utang akan menimbulkan terjadinya penurunan nilai perusahaan.

\section{Hasil Uji Hipotesis 4}

Tabel 4. Ringkasan Hasil Uji Hipotesis 4

\begin{tabular}{lccccr}
\hline Variabel & B & Beta & $t_{\text {hitung }}$ & $t_{\text {tabel }}$ & Sig. \\
\hline ZCSR & 0,047 & 0,031 & 1,038 & 1,993 & 0,302 \\
ZKMANJ & & 0,011 & 0,294 & & 0,770 \\
AbsCSR_ & 0,117 & 3,143 & & 0,002 \\
KMANJ & & & \\
\hline Berdasarkan & tabel & 9, & persamaan & regres \\
adalah : & & & \\
Tobin’s & & & \\
0,047 + 0,031 CSR + 0,011 K. MANJ + \\
0,117 | CSRK - MANJ |
\end{tabular}

Berdasarkan tabel 9, dapat dilihat bahwa nilai thitung variabel interaksi antara CSR dan Kepemilikan Manajerial (AbsCSR_KMANJ) sebesar 3,143 sedangkan $\mathrm{t}_{\text {tabel }}$ pada tingkat signifikansi $5 \%$ (uji 2 sisi) sebesar 1,993. Hasil ini menunjukkan bahwa thitung lebih besar dari $t_{\text {tabel }}(3,143>1,993)$. Nilai probabilitas signifikansi sebesar 0,002 menunjukkan nilai yang lebih kecil dari nilai pada tingkat signifikansi yang telah ditentukan sebelumnya, yaitu $0,05(0,002>0,05)$. Berdasarkan hasil uji hipotesis tersebut dapat disimpulkan bahwa variabel Kepemilikan Manajerial (K.MANJ) mampu memoderasi pengaruh CSR terhadap Nilai Perusahaan (Tobin's Q).

Hasil penelitian ini sesuai dengan hasil penelitian yang dilakukan oleh Laras Surya Ramadhani dan Basuki Hadiprajitno (2012). Hasil penelitian tersebut menyimpulkan bahwa Kepemilikan Manajerial mampu memoderasi hubungan antara CSR terhadap Nilai Perusahaan. Perusahaan yang memiliki kepemilikan manajerial yang tinggi dapat meningkatkan nilai perusahaan melalui pengungkapan Corporate Social Responsibility oleh perusahaan.

\section{Hasil Uji Hipotesis 5}

Tabel 10. Ringkasan Hasil Uji Hipotesis 5

\begin{tabular}{llllll}
\hline Variabel & $\mathrm{B}$ & $\mathrm{Beta}$ & $\mathrm{t}_{\text {hitung }}$ & $\mathrm{t}_{\text {tabel }}$ & Sig. \\
\hline ZMBVE & 0,114 & 0,252 & 15,085 & 1,993 & 0,000 \\
ZKMANJ & & - & $-2,770$ & & 0,007 \\
& & 0,047 & & & \\
AbsMBVE_ & & 0,070 & 2,705 & & 0,009 \\
KMANJ & & & & & \\
\hline
\end{tabular}

Berdasarkan tabel 10, persamaan regresi adalah :

Tobin's

$, 114+0,252$ MBVE -

0,047 K.MANJ + 0,070|MBVE K. MANJ | 


\section{JURNAL NOMINAL / VOLUME V NOMOR 2 / TAHUN 2016}

Berdasarkan tabel 10 , nilai $t_{\text {hitung }}$ variabel interaksi antara Keputusan Investasi dan Kepemilikan

Manajerial (AbsMBVE_KMANJ) adalah sebesar 2,705 sedangkan $t_{\text {tabel }}$ pada tingkat signifikansi $5 \%$ (uji 2 sisi) sebesar 1,993. Hasil ini menunjukkan bahwa thitung lebih besar dari $t_{\text {tabel }}(2,705>1,993)$. Nilai probabilitas signifikansi sebesar 0,009 menunjukkan nilai yang lebih kecil dari nilai pada tingkat signifikansi yang telah ditentukan sebelumnya, yaitu $0,05(0,009>0,05)$. Berdasarkan hasil uji hipotesis tersebut dapat disimpulkan bahwa variabel Kepemilikan Manajerial (K.MANJ) mampu memoderasi pengaruh Keputusan Investasi (MBVE) terhadap Nilai Perusahaan (Tobin's Q).

Pihak manajemen yang memiliki saham di perusahaan menginginkan adanya peningkatan nilai perusahaan. Berdasarkan hasil penelitian ini, semakin meningkatnya kepemilikan saham oleh manajemen telah menjadikan pihak manajemen membuat keputusan yang dapat meningkatkan kemakmuran pemegang saham dimana pihak manajer juga menjadi pemegang saham. hasil ini sesuai dengan yang dijelaskan dalam teori keagenan.

Manajer mampu memanfaatkan peluang-peluang investasi untuk memberikan sinyal positif mengenai pertumbuhan perusahaan di masa yang akan dating sesuai dengan teori sinyal (Signalling
Theory). Keputusan investasi yang dilakukan oleh manajer mampu memakmurkan pemegang saham yang artinya meningkatkan nilai perusahaan. Oleh karena itu, kepemilikan manajerial dapat memoderasi pengaruh keputusan investasi terhadap nilai perusahaan.

\section{Hasil Uji Hipotesis 6}

Tabel 6. Ringkasan Hasil Uji Hipotesis 6

\begin{tabular}{llllll}
\hline Variabel & B & Beta & $t_{\text {hitung }}$ & $t_{\text {tabel }}$ & Sig. \\
\hline ZDER & 0,146 & - & - & 1,993 & 0,001 \\
& & 0,114 & 3,587 & & \\
ZKMANJ & & 0,111 & 3,472 & & 0,001 \\
AbsDER_- & & 0,029 & 0,638 & & 0,525 \\
KMANJ & & & & & \\
\end{tabular}

Berdasarkan tabel 6, persamaan regresi adalah :

Tobin's

0,146 - 0,114 DER+

\section{0,111 K.MANJ + 0,029 |DER - K. MANJ |}

Berdasarkan tabel 6, dapat dilihat bahwa nilai $t_{\text {hitung }}$ variabel interaksi antara Struktur Modal dan Kepemilikan Manajerial (AbsDER_KMANJ) sebesar 0,638 sedangkan $t_{\text {tabel }}$ pada tingkat signifikansi $5 \%$ (uji 2 sisi) sebesar 1,993. Hasil ini menunjukkan bahwa thitung lebih kecil dari $t_{\text {tabel }}(0,638>1,993)$. Nilai probabilitas signifikansi sebesar 0,525 menunjukkan nilai yang lebih besar dari nilai pada tingkat signifikansi yang telah ditentukan sebelumnya, yaitu $0,525(0,525>0,05)$. Berdasarkan hasil uji hipotesis tersebut 


\section{JURNAL NOMINAL / VOLUME V NOMOR 2 / TAHUN 2016}

dapat disimpulkan bahwa variabel Kepemilikan Manajerial (K.MANJ) tidak mampu memoderasi pengaruh Struktur Modal (DER) terhadap Nilai Perusahaan (Tobin's Q).

Hasil penelitian ini sesuai dengan hasil penelitian dari Komang Samisi dan Putu Agus Ardiana (2013). Hasil penelitian tersebut menyimpulkan bahwa Kepemilikan Manajerial tidak mampu memoderasi hubungan antara Struktur Pendanaan dengan Nilai Perusahaan. Kepemilikan manajerial yang relatif rendah menyebabkan pihak manajemen tidak memiliki kekuasaan yang penuh atas perusahaan. Manajemen dalam pengambilan keputusan yang memiliki dampak besar terhadap perusahaan harus mendapatkan persetujuan terlebih dahulu dari pemegang saham mayoritas.

Namun, berdasarkan hasil penelitian, tingkat kepemilikan saham yang dimiliki oleh manajer tidak mampu menyeimbangan pendanaan antara modal sendiri dan utang, dimana ditunjukkan dengan tingginya nilai DER, yang dapat diartikan bahwa tingkat pendanaan melalui utang pada perusahaan pertambangan termasuk tinggi. Oleh karena itu, Kepemilikan Manajerial tidak mampu memoderasi pengaruh Struktur Modal terhadap Nilai Perusahaan.

\section{Hasil Uji Hipotesis 7}

Tabel 7. Ringkasan Hasil Uji Hipotesis 7

\begin{tabular}{llllll}
\hline Variabel & $\mathrm{B}$ & Beta & $\mathrm{R}^{2}$ & $\mathrm{~F}_{\text {hitung }}$ & Sig. \\
\hline CSR & 0,036 & $-0,069$ & 0,777 & 84,924 & 0,000 \\
MBVE & & 0,588 & & & \\
DER & & $-0,083$ & & & \\
\hline
\end{tabular}

Berdasarkan tabel 7 , persamaan regresi adalah :

Tobin's $\mathrm{Q}=0,036-0,069 \mathrm{CSR}+0,588$ MBVE $-0,083$ DER $+\varepsilon$

Berdasarkan tabel 7, dapat dilihat bahwa nilai $F_{\text {hitung }}$ sebesar 84,924 dengan probabilitas signifikansi sebesar 0,000 menunjukkan nilai yang lebih kecil dari nilai pada tingkat signifikansi yang telah ditentukan sebelumnya, yaitu 0,05 (0,000 > 0,05). Dengan nilai probabilitas yang lebih kecil dari tingkat signifikansi tersebut, maka model regresi ini dapat digunakan untuk memprediksi Nilai Perusahaan (Tobin's Q).

Berdasarkan hasil uji hipotesis tersebut dapat disimpulkan bahwa variabel CSR, Keputusan Investasi (MBVE), dan Struktur Modal (DER) secara bersama-sama berpengaruh terhadap Nilai Perusahaan (Tobin's Q).

Pelaksanaan Corporate Social Responsibility oleh perusahaan akan menjamin nilai perusahaan tumbuh secara berkelanjutan. Pertumbuhan perusahaan menjadikan perusahaan akan melakukan pengeluaran investasi yang dapat memberikan sinyal positif dan meningkatkan nilai perusahaan melalui 


\section{JURNAL NOMINAL / VOLUME V NOMOR 2 / TAHUN 2016}

kegiatan investasi. Pemilihan kegiatan investasi berhubungan dengan pendanaan dalam struktur modalnya. Perusahaan yang tumbuh dengan cepat membutuhkan modal yang besar dan akan memiliki kesempatan untuk meminjam lebih besar. Perusahaan dengan kesempatan investasi yang tinggi harus diimbangi pula dengan bertambahnya modal. Bertambahnya Modal ini harus mampu diseimbangkan antara penggunaan modal eksternal, yaitu utang dan modal sendiri untuk memperoleh stuktur modal yang optimal. Dengan demikian, pihak manajemen harus menerapkan CSR untuk menjamin Nilai Perusahaan tumbuh dengan Stuktur Modal yang optimal. Oleh karena itu, CSR, Keputusan Investasi, dan Struktur Modal akan secara bersama-sama berpengaruh terhadap Nilai Perusahaan.

\section{SIMPULAN DAN SARAN}

\section{Simpulan}

1. CSR berpengaruh positif dan tidak signifikan terhadap Nilai Perusahaan pada perusahaan sektor pertambangan yang terdaftar di Bursa Efek Indonesia periode 2008-2014. Hasil ini berdasarkan tabel 25 yang menunjukkan bahwa nilai $\mathrm{t}_{\text {hitung }}$ sebesar 1,195 lebih kecil jika dibandingkan dengan tabel pada tingkat signifikansi 0,05 , yaitu sebesar 1,666 $(1,195<1,666)$. Nilai probabilitas signifikansi sebesar 0,236 menunjukkan nilai yang lebih besar dari nilai pada tingkat signifikansi yang sebelumnya telah ditentukan, yaitu $0,05 \quad(0,236>$ 0,05). Oleh karena itu, dapat disimpulkan bahwa CSR memiliki pengaruh positif dan tidak signifikan terhadap Nilai Perusahaan (Tobin's Q).

2. Keputusan Investasi berpengaruh positif dan signifikan terhadap Nilai Perusahaan pada perusahaan sektor pertambangan yang terdaftar di Bursa Efek Indonesia periode 2008-2014. Hasil ini berdasarkan tabel yang menunjukkan bahwa nilai thitung sebesar 15,902 lebih besar jika dibandingkan dengan $t_{\text {tabel }}$ pada tingkat signifikansi 0,05 , yaitu sebesar 1,666 $(15,902>1,666)$. Nilai probabilitas signifikansi sebesar 0,000 menunjukkan nilai yang lebih kecil dari nilai pada tingkat signifikansi yang sebelumnya telah ditentukan, yaitu $0,05 \quad(0,000<$ 0,05). Oleh karena itu, dapat disimpulkan bahwa Keputusan Investasi (MBVE) memiliki pengaruh positif dan signifikan terhadap Nilai Perusahaan (Tobin's Q).

3. Struktur Modal berpengaruh negatif dan signifikan terhadap Nilai Perusahaan pada perusahaan sektor pertambangan yang terdaftar di Bursa Efek Indonesia periode 2008-2014. Hasil ini berdasarkan tabel 27 yang menunjukkan bahwa nilai thitung sebesar -2,238 lebih besar jika dibandingkan dengan tabel pada tingkat signifikansi 0,05, yaitu sebesar -1,666 (2,238> -1,666). Nilai probabilitas 


\section{JURNAL NOMINAL / VOLUME V NOMOR 2 / TAHUN 2016}

signifikansi sebesar 0,028 menunjukkan nilai yang lebih kecil dari nilai pada tingkat signifikansi yang sebelumnya telah ditentukan, yaitu $0,05 \quad(0,028<$ 0,05). Oleh karena itu, dapat disimpulkan bahwa Struktur Modal (DER) memiliki pengaruh negatif dan signifikan terhadap Nilai Perusahaan (Tobin's Q).

4. Kepemilikan Manajerial mampu memoderasi pengaruh CSR terhadap Nilai Perusahaan pada perusahaan sektor pertambangan yang terdaftar di Bursa Efek Indonesia periode 2008-2014. Hasil ini dapat diketahui berdasarkan tabel 28 yang menunjukkan bahwa nilai $t_{\text {hitung }}$ variabel interaksi antara CSR dan Kepemilikan Manajerial (AbsCSR_K.MANJ) sebesar 3,143 lebih besar jika dibandingkan dengan $t_{\text {tabel }}$ pada tingkat signifikansi 0,05 (uji 2 sisi), yaitu sebesar $1,993(3,143>1,993)$. Nilai probabilitas signifikansi sebesar 0,002 variabel interaksi antara CSR dan Kepemilikan Manajerial (AbsCSR_K.MANJ) menunjukkan nilai yang lebih kecil dari nilai pada tingkat signifikansi yang sebelumnya telah ditentukan, yaitu 0,05 $(0,002>0,05)$.

5. Kepemilikan Manajerial mampu memoderasi pengaruh Keputusan Investasi terhadap Nilai Perusahaan pada perusahaan sektor pertambangan yang terdaftar di Bursa Efek Indonesia periode 2008-2014. Berdasarkan tabel 29 diketahui bahwa nilai $t_{\text {hitung }}$ pada variabel interaksi antara Keputusan Investasi dan Kepemilikan Manajerial (AbsMBVE_K.MANJ) sebesar 2,705 lebih besar jika dibandingkan dengan $t_{\text {tabel }}$ pada tingkat signifikansi 0,05 (uji 2 sisi), yaitu sebesar 1,993 (2,705> 1,993). Nilai probabilitas signifikansi sebesar 0,009 pada variabel interaksi antara Keputusan Investasi dan Kepemilikan Manajerial (AbsMBVE_K.MANJ) menunjukkan nilai yang lebih kecil dari nilai pada tingkat signifikansi yang sebelumnya telah ditentukan, yaitu 0,05 (0,009 > $0,05)$.

6. Kepemilikan Manajerial tidak mampu memoderasi pengaruh Struktur Modal terhadap Nilai Perusahaan pada perusahaan sektor pertambangan yang terdaftar di Bursa Efek Indonesia periode 2008-2014. Hasil ini dapat diketahui berdasarkan tabel 30 yang menunjukkan bahwa nilai thitung variabel interaksi antara Struktur Modal dan Kepemilikan Manajerial (AbsDER_K.MANJ) sebesar 0,638 lebih besar jika dibandingkan dengan $t_{\text {tabel }}$ pada tingkat signifikansi 0,05 (uji 2 sisi), yaitu sebesar 1,993 (0,638 > 1,993). Nilai probabilitas signifikansi sebesar 0,525 pada variabel interaksi antara Struktur Modal dan Kepemilikan Manajerial (AbsDER_K.MANJ) menunjukkan nilai yang lebih besar dari nilai pada tingkat signifikansi yang 


\section{JURNAL NOMINAL / VOLUME V NOMOR 2 / TAHUN 2016}

sebelumnya telah ditentukan, yaitu 0,05 $(0,525>0,05)$.

7. CSR, Keputusan Investasi, dan Struktur Modal berpengaruh secara bersama-sama dan signifikan terhadap Nilai Perusahaan pada perusahaan sektor pertambangan yang terdaftar di Bursa Efek Indonesia periode 2008-2014. Hasil ini ditunjukkan berdasarkan tabel 31 yang menunjukkan bahwa nilai $F_{\text {hitung }}$ sebesar 84,924. Nilai probabilitas signifikansi sebesar 0,000 menunjukkan nilai yang lebih kecil dari nilai pada tingkat signifikansi yang sebelumnya telah ditentukan, yaitu 0,05 $(0,000<0,05)$. Oleh karena itu, dapat disimpulkan bahwa CSR, Keputusan Investasi (MBVE), dan Struktur Modal (DER) berpengaruh secara bersama-sama dan signifikan terhadap Nilai Perusahaan (Tobin's Q).

\section{SARAN}

1. Bagi investor

Investor harus mempertimbangkan berbagai aspek ketika akan melakukan investasi di perusahaan, salah satunya dari CSR. Investor dalam memutuskan akan berinvestasi, sebaiknya memilih pada perusahaan yang telah menerapkan tanggung jawab sosialnya secara konsisten. Berdasarkan hasil penelitian ini, kualitas pengungkapan CSR masih rendah sehingga investor harus selektif dalam memilih perusahaan yang akan ditanamkan modalnya. Pertimbangan kedua adalah Keputusan Investasi yang diproksikan dengan Investment Opportunity Set (IOS). Berdasarkan hasil penelitian ini, yaitu menunjukkan bahwa perusahaan mampu memanfaatkan kesempatan investasi sehingga dapat meningkatkan nilai perusahaan. Pertimbangan ketiga adalah proporsi Struktur Modal. Berdasarkan hasil penelitian ini adalah perusahaan lebih banyak menggunakan utang sebagai pendanaannya sehingga beban risiko yang ditanggung lebih besar. Ketika akan berinvestasi, investor hendaknya mempertimbangkan penentuan struktur modal oleh perusahaan. Pertimbangan keempat adalah Kepemilikan Manajerial. Perusahaan yang memberikan kebijakan adanya kepemilikan saham oleh pihak manajemen akan menjadikan pihak manajemen lebih berhati-hati dalam membuat keputusan.

2. Bagi perusahaan

a. Perusahaan hendaknya lebih memperhatikan penerapan dan pelaporan CSR berdasarkan standar yang telah dikeluarkan Global Reporting Index (GRI). Dengan demikian, diharapkan dapat meningkatkan Nilai Perusahaan.

b. Perusahaan hendaknya mampu menentukan Keputusan Investasi yang tepat sehingga dapat memberikan sinyal yang positif bagi pihak eksternal. Dengan 


\section{JURNAL NOMINAL / VOLUME V NOMOR 2 / TAHUN 2016}

demikian,

diharapkan

meningkatkan Nilai Perusahaan.

c. Perusahaan hendaknya dapat menentukan struktur modal yang optimal, yaitu penggunaan antara utang dan modal sendiri sehingga diharapkan dapat meningkatkan Nilai Perusahaan.

3. Bagi peneliti selanjutnya

a. Penelitian selanjutnya sebaiknya melakukan penelitian serupa dengan sektor yang berbeda dan dengan jumlah sampel yang lebih banyak.

b. Penelitian ini menggunakan Tobin's Q untuk memproksikan Nilai perusahaan. Penelitian selanjutnya diharapkan dapat menggunakan proksi yang lain, seperti PBV dan PER.

c. Penelitian ini menggunakan Market to Book Value of Equity Ratio (MBVE) untuk memproksikan Keputusan Investasi. Penelitian selanjutnya diharapkan dapat menggunakan proksi yang lain, seperti MBVA, PER, PPEBVA, CAPBVA, CAPMVA, CAONS, atau VARRET. Penggunaan proksi lain diharapkan dapat lebih menggambarkan variabel Keputusan Investasi.

d. Penelitian ini menggunakan Kepemilikan Manajerial sebagai variabel pemoderasi. Penelitian selanjutnya, diharapkan dapat menggunakan variabel lain, seperti profitabilitas, leverage, atau size untuk mendapatkan hasil yang lebih bervariasi.

\section{DAFTAR PUSTAKA}

Arie Afzal dan Abdul Rohman. (2012). Pengaruh Keputusan Investasi, Keputusan Pendanaan dan Kebijakan Deviden Terhadap Nilai Perusahaan. Diponegoro Journal of Accounting. 1 (2), 9 .

Brigham dan Houston. 2010. Dasar-Dasar Manajemen Keuangan Edisi 11 Buku 1 (Alih Bahasa : Ali Akbar Yulianto). Jakarta : Salemba Empat.

Eli Safrida (2008). Pengaruh Struktur Modal dan Pertumbuhan Terhadap Nilai Perusahaan Pada Perusahaan Manufaktur Di Bursa Efek Jakarta. Tesis, Universitas Sumatera Utara.

Imam Ghozali. 2011. Aplikasi Analisis Multivariate Dengan Program IBM SPSS 19 Edisi 5. Semarang : Badan Penerbit Universitas Diponegoro.

Komang Samisi dan Putu Agus Ardiana (2013). Pengaruh Struktur Pendanaan Terhadap Nilai Perusahaan Dengan Kepemilikan Manajerial Sebagai Variabel Moderasi. E-Jurnal Akuntansi Universitas Udayana. 5.2 (2), 451-469.

Laras Surya Ramadhani dan Basuki Hadi Prajitno (2014). Pengaruh Corporate Social Responsibility Terhadap Nilai Perusahaan Dengan Prosentase Kepemilikan Manajemen Sebagai Variabel Moderating Pada Perusahaan Manufaktur Yang Terdaftar di BEI. Universitas Diponegoro.

Rika Nurlela dan Islahudin. (2008). Pengaruh Corporate Social Responsibility Terhadap Nilai Perusahaan Dengan Prosentase Kepemilikan Manajemen Sebagai Variabel Moderating (Studi Empiris Pada Perusahaan Yang Terdaftar di 
Bursa Efek Jakarta). Simposium Nasional Akuntansi XI Pontianak.

Riskin Hidayat. (2010). Keputusan Investasi dan Financial Constraints : Studi Empiris Pada Bursa Efek Indonesia. Buletin Ekonomi Moneter dan Perbankan, April 2010.

Lihan Rini Puspo Wijaya dan Bandi Anas Wibawa. (2010). Pengaruh Keputusan Investasi, Keputusan Pendanaan dan Kebijakan Deviden terhadap Nilai Perusahaan. Simposium Nasional Akuntansi XIII Purwokerto.

Puguh Suharso. 2009. Metode Penelitian Kuantitatif Untuk Bisnis: Pendekatan Filosofi dan Praktis. Jakarta : PT INDEKS.

Sutopoyudo. (2009). Pengaruh Penerapan Corporate Social Responsibility (CSR) Terhadap Profitabilitas Perusahaan. Diakses tanggal 13 November 2015 dari

https://sutopoyudo.wordpress.com/200 9/09/21/pengaruh-penerapancorporate-social-responsibility-csrterhadap-profitabilitas-perusahaan/. 